ORNL/Sub/85-27413/7

\title{
PERENNIAL SPECIES FOR OPTIMUM PRODUCTION \\ OF HERBACEOUS BIOMASS IN THE PIEDMONT \\ (MANAGEMENT STUDY, 1987-1991)
}

\section{Final Report}

David J. Parrish, Dale D. Wolf, and W. Lee Daniels Department of crop and Soil Environmental Sciences Virginia Polytechnic Institute and state University

Blacksburg, Virginia 24061-0404

Date Published - April 1993

Report Prepared by

Virginia Polytechnic Institute and State University Blacksburg, Virginia 24061 under

Subcontract $19 \mathrm{X}-27413 \mathrm{C}$

Research supported by Biofuels System Division

Office of Transportation Technologies Activity No. EB 2413010

Prepared for

Biofuels Feedstock Development Program Environmental Sciences Division OAK RIDGE NATIONAL LABORATORY

Oak Ridge, Tennessee 37831-6285 managed by

MARTIN MARIETTA ENERGY SYSTEMS, INC. for the

U.S. DEPARTMENT OF ENERGY

under contract DE-AC05-840R2 1400 
TABLE OF CONTENTS

List of Figures . . . . . . . . . . . . . . . . . v

List of Tables . . . . . . . . . . . . . . . . vii

Acknowledgements . . . . . . . . . . . . . . . xi

Abstract . . . . . . . . . . . . . . . . . xiii

Chapter 1: Introduction and Overview . . . . . . . . 1

Chapter 2: Harvest and Nitrogen . . . . . . . . . 5 Management for Switchgrass and Weeping Lovegrass Produced as Energy Crops

Chapter 3: Double-Cropping with Rye and . . . . . 15 Winter-Annual Legumes in a Switchgrass Biomass Production system

Chapter 4: Summary and Conclusions . . . . . . . 23 


\section{LIST OF FIGURES}

Figure 2-1: Map showing sites for biomass . . . . . 6 screening study in the

Virginia Piedmont, 1985-1989 


\section{LIST OF TABLES}

Table 2-1:

Seasonal biomass yields . . . . . . . . 7 (1988) of switchgrass and weeping lovegrass fertilized at three different $\mathrm{N}$ rates. Lovegrass was cut either once (early-November) or twice (early september and earlyNovember). Switchgrass was cut once, either early (earlySeptember) or late (earlyNovember). Sites were located on Davidson soils in orange county, VA, and on Cecil soils in Amelia county, VA.

Table 2-2: Seasonal biomass yields . . . . . . . . . 8
(1989) of switchgrass and
weeping lovegrass fertilized at three different $\mathrm{N}$ rates. Lovegrass was cut either once (early-November) or twice (early-september and earlyNovember). Switchgrass was cut once, either early (earlySeptember) or late (earlyNovember). Sites were located on Davidson soils in orange county, VA, and on Cecil soils in Amelia county, VA.

Table 2-3:

Seasonal biomass yields . . . . . . . 9 (1990) of switchgrass and weeping lovegrass fertilized at three different $\mathrm{N}$ rates. Each was cut once, either early (early-september) or late (early-November). Sites were located on Davidson soils in orange county, VA, and on Cecil soils in Amelia County, VA. 
Table 3-2:

Table 3-3:

Table 3-4:

Table 3-5:

Table 3-6:

Table 3-6:

Table 3-7:

Table 3-8:

Biomass of switchgrass grown. on two sites in the virginia piedmont following fertilization with three $N$ rates or three winter-annual legume cover crops. Harvests were made in september 1989.

Yield of rye double-cropped . . . . . 18 with switchgrass and yield of switchgrass following rye or single-cropped when grown on two soils in the Virginia Piedmont, 1989.

Biomass in switchgrass plots . . . . 18 interplanted with winterannual legumes at three sites in the Virginia Piedmont, May 1990 .

Biomass of switchgrass grown . . . . 19 on three sites in the virginia piedmont following fertilization with three rates of $\mathrm{N}$ or three winter-annual legume cover crops. Harvests were made in September 1990.

Yield of rye double-cropped . . . . . 19 with switchgrass and yield of switchgrass following rye or single-cropped when grown on three sites in the Virginia Piedmont, 1990 .

Biomass of switchgrass plots . . . . 20 interplanted with winterannual legumes or rye at three sites in the virginia Piedmont, April 1991.

Biomass of switchgrass grown . . . . . 21 on three sites in the virginia piedmont following fertilization with three rates of $N$, three winter-annual legume cover crops, or a rye double crop. Harvests were made in November 1991. 


\section{ACKNOWLEDGEMENTS}

The authors are grateful to several individuals whose assistance was invaluable in the accomplishment of this study. Thanks go first of all to the several graduate students who provided much of the day-to-day and season-toseason labor. Those tireless individuals included David Aho, Dale Ball, Mike Genthner, David Hall, Steve Nagle, Preston Sullivan, and Zsusana Trocsanyi.

We especially appreciate the cooperation of individuals who permitted us to do these studies on their land. Their sites were uniquely well-suited to the work, and they were very kind to allow us to use them. These generous land owners were Mr. Robert E. Wilkinson, Jr. and the late iMr. Robert E. Wilkinson, Sr. of Kenbridge, Virginia. In addition, Mr. David Ellinghausen (Amelia Game Preserve) and Mr. David Starner (Northern Piedmont Agricultural Experiment station) were very kind in their permission to use both land and equipment for this work. We acknowledge with especial gratitude the very considerable interest and efforts of $\mathrm{Mr}$. starner and his fine staff of technicians in behalf of this project.

We thank Ms. Sybil Paul for her excellent and cheerful efforts in preparation of this manuscript.

Finally, we wish to thank Ms. Janet Cushman and Mr. Anthony Turhollow for their encouragement, support, and direction. It has been a pleasant and rewarding experience for us. 


\section{ABSTRACT}

We have investigated cutting and $\mathrm{N}$ management strategies for two biofuel feedstock candidate species -- switchgrass (Panicum virgatum) and weeping lovegrass (Eragrostis curvula). Each was no-till planted in 1987 at three sites underlain by Davidson or Cecil soils. Three $\mathrm{N}$ levels $(0,50$, or $100 \mathrm{~kg} / \mathrm{ha}$ ) were applied, and the plots fertilized at each level were harvested either twice (early-September and earlyNovember) or only in early-November. The results with lovegrass suggest $50 \mathrm{~kg} \mathrm{~N} / \mathrm{ha}$ is nearly optimal and that two cuttings provide more biomass than one.

For switchgrass, when averaged across sites and years, $50 \mathrm{~kg} \mathrm{~N} / \mathrm{ha}$ produced a slight yield advantage over no added $\mathrm{N}$, but $50 \mathrm{~kg}$ was not different from $100 \mathrm{~kg}$. In 1989 and 1990, more biomass was available in early-september harvests $(9.6$ $\mathrm{Mg} / \mathrm{ha}$ ) than in early-November $(8.3 \mathrm{Mg} / \mathrm{ha})$. Apparently the plants translocated significant portions of their biomass below ground during the last few weeks of the season. In 1991, we harvested only in early-November. Plots that had been cut in early-september in the previous three years had lower yields $(7.6 \mathrm{Mg} / \mathrm{ha})$ than those that had been cut only in early-November $(9.4 \mathrm{Mg} / \mathrm{ha})$. The delayed cutting permitted more growth on a sustained basis -- presumably because of conservation of translocatable materials. This poses an interesting dilemma for the producer of biomass.

In additional studies, we found no advantage in doublecropping rye (secale cer ale) with switchgrass; at low input levels, rye yields were low, and rye lowered switchgrass yields. Other studies showed double-cropping with winterannual legumes such as crimson clover (Trifolium incarnatum) may have potential. The timing of herbicide treatment of the legume is critical.

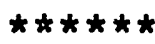

Parrish, D. J., D. D. Wolf, and W. L. Daniels. 1993. Perennial species for optimal Production of Herbaceous Biomass in the Piedmont (Management study), Final Report, 1987-1991. ORNL/Sub/85-27413/7. Oak Ridge National Laboratory, Oak Ridge, Tennessee. 


\section{CHAPTER ONE}

\section{INTRODUCTION AND OVERVIEW}

Mankind's great mobility currently relies upon liquid fuels processed from fossil energy supplies. Petrofuels are being depleted, however, and the return of their fossilized carbon to the atmosphere appears to have climate-altering consequences (Kerr, 1988). Commerce needs a renewable liquid-fuel source, ideally one that recycles carbon. Energy-cropping, the production of biomass for conversion to liquid fuels, may help respond to both needs.

But, can energy-cropping compete economically with other agricultural enterprises? Perhaps more importantly, can large-scale energy-cropping occur without taking prime agricultural land out of food, feed, and fiber production (El-Hinnawi, 1981; Hall, 1979; USDOE, 1979)? If marginal agricultural land, which is economically or environmentally unsuitable for row-cropping, were used for energy-cropping, the answer to both of these critical questions could be "yes". Energy-cropped land probably cannot provide a high return to its owner, but marginal land often is not providing any return. Rather, it is idle or producing at such low levels that it is uneconomic; and, by definition, marginal land is not in prime competition for production of food, feed, and fiber crops.

Many users of land that is marginally productive must still earn a living from that land. In this predicament, they often resort to unsound cropping practices. The severely eroded slopes that characterize much of the Piedmont of North America are one example of the consequenres of being forced to subsist on marginal land. Much of the lower Piedmont was cleared and cultivated by 1800 ; and, by 1900, most of its rich topsoil was eroded away, leaving exposed the clayey, acidic, and frequently rocky subsoil (Trimble, 1974). Consequent declines in productivity, along with the Depression of the early 1930s, finally halted the intensive cultivation of much of the piedmont. The majority of the land has now returned to forest, but tens of thousands of hectares remain cleared. This marginal land, too steep for row cropping and not in managed forests, might be made productive again through energy-cropping.

We do not propose that energy-cropping on marginal agricultural land might be a total solution to regional or global energy problems. sunlight is diffuse, and photosynthesis is not efficient in conversion of ligit energy to chemical energy, especially in temperate areas (Braunstein 
et al., 1981; Hall, 1979). But photosynthetic energy storage is the only renewable energy technology currently deployed on a large scale (El-Hinnawi, 1981). Energy-cropping, therefore, demands careful consideration (Hills et al., 1981; Linden et al., 1984; Parrish et al., 1985; Wedin and Helsel, 1980). If suitable energy crops and practices can be found, marginal agricultural land could be made energetically and economically productive; and the renewable fuels produced could reduce pressure on dwindling, nonrenewable sources and on atmospheric/climatic changes.

This project was initiated under the Herbaceous Energy Crops Program (HECP), which is now a part of the Biofuels Feedstock Development Program. The HECP, as initially conceived, sought to identify nonwoody species that can produce biomass cost-effectively when grown on marginal land. our objective, as one component of the HECP, was to look specifically at marginal sites in the piedmont and to identify those species and methods that might make energycropping practical there. This overall objective was addressed in a series of related tasks, each subsumed under a specific objective. The seven objectives of the 5-year project formally approved for study at Virginia Tech were:

One: Define the soil morphological, chemical, physical, and mineralogical parameters that characterize marginally productive ( 6 to $12 \%$ slope) sites underlain by three major piedmont soil types (Appling, Cecil, and Davidson).

Two: Examine a select group of herbaceous perennials for biomass yield on Appling, Cecil, and Davidson soils on slopes of 6 to $12 \%$ in the Virginia Piedmont.

Three: Document economics of production and harvesting of each energy crop candidate species on each soil type identified.

Four: Consider the effect of biomass production on annual runoff and annual sediment yield as determined by the Universal Soil Loss Equation.

Five: Identify soil/site factors most likely to be limiting productivity on the three soil types from objective one and relate these factors to soil/crop management requirements for a range of Piedmont soils. 
Six: Develop management procedures for most economic biomass production on each type of soil.

Seven: Investigate potential yield-limiting processes (e.g. seed dormancy, photosynthesis, and water use efficiency) of warm-season grass biomass candidates.

Objectives one, Two, and Five were addressed in a major screening study, which investigated marginal soils/sites and candidate biomass species. Objectives Three (economics) and Four (erosion) were developed using data obtained in the screening study (Vaughan et al., 1989). objective seven (physiology) was distinct from the screening study, but followed logically from its early findings. Findings from each of these objectives were reported to the contractor in 1990 (Parrish et al., 1990).

This report focuses solely on the work associated with objective six (management). Initial phases of our "Management study" have been previously reported (Parrish et al., 1990), but this report will cover the entire span of the research on Objective Six (1987 to 1991). The Management study dealt with two species, switchgrass (Panicum virgatum) and weeping lovegrass (Eragrostis curvula), which emerged as the most promising candidates from objective Two's Screening study.

A nitrogen-management component of objective six was addressed in two ways. In one, we looked at the effect of adding synthetic fertilizer nitrogen at various rates. We simultaneously looked for possible effects of cutting date/frequency. Those results are reported in chapter Two. We also looked at the possibility of using winter-annual legumes as a nitrogen source for switchgrass. We eventually tried four different double-cropped legumes. In the context of double-cropping, we also looked at winter rye planted into the stubble of harvested switchgrass. The results of these double-cropping research efforts are reported in chapter Three. Chapter Four presents a general summation and conclusions.

\section{REFERENCES}

Braunstein, H. M., Kanciruk, P., Roop, R. D., Sharples, F. E., Tatum, J. S., and Oakes, K. M., Biomass Energy Systems and the Environment. New York: Pergamon Press, 1981. 
El-Hinnawi, E. E., The Environmental Impacts of Production and Use of Energy. Shannon, Ireland: Irish Elsevier Printers, 1981 .

Hall, D. D., "Solar energy use through biology," Solar Energy 22, 307 (1979).

Hills, F. J., Johnson, S. S., Geng, S., Abshahi, A., and Peterson, G. R., "Comparison of high-energy crops for alcohol production," California Agriculture 35(12), 14-16. (1981).

Kerr, R. A., "Is a climate jump in store for earth?" Science 239, 259-260 (1988).

Linden, J. C., Murphy, V. G., and Smith, D. H., "Forage crops as chemical feedstocks." In: Bioconversion systems, ed. D. L. Wise. Boca Raton, Florida: CRC Press, pp. 71-87. 1984.

Parrish, D. J., Gammon, T. C., and Graves, B., "Production of fermentables and biomass by six temperate fuelcrops," Energy in Agriculture 4 , 319-330 (1985).

Parrish, D. J., Wolf, D. D., Daniels, W. L., Vaughan, D. H., and Cundiff, J. S., "Perennial species for optimum productions of herbaceous biomass in the Piedmont," Final report 1985-89. Oak Ridge National Laboratory: U. S. Dept. of Energy, 1990.

Trimble, S. W., Man-Induced soil Erosion on the southern Piedmont: 1700-1970. Ankeny, Iowa: Soil Conservation Society of America, 1974.

United States Department of Energy. Environmental Readiness Document: Biomass Energy Systems. Washington, D.C.: U. S. Dept. of Energy, 1979.

Vaughan, D. H., Cundiff, J. S., and Parrish, D. J., "Herbaceous crops on marginal sites-erosion and economics," Biomass 20, 199-208. 1989.

Wedin, W. F. and Helsel, Z., "Plant species for biomass production on marginal sites," In: Fuels From Biomass, ed. J. S. Robinson. Park Ridge, New Jersey: Noyes Data Corp. pp. 74-78. 1980 . 


\section{CHAPTER TWO}

\section{HARVEST AND NITROGEN MANAGEMENT FOR SWITCHGRASS AND WEEPING LOVEGRASS PRODUCED AS ENERGY CROPS}

Objective Six of Virginia Tech's HECP project dealt with management techniques to improve productivity of two biomass candidates, switchgrass and lovegrass. What practices might a grower use to increase yield and reduce costs of production of these crops? We focused in the Management study on two areas: $\mathrm{N}$ fertility and cutting frequency. Nitrogen fertilizer is relatively expensive, and it poses some threat to surface and ground waters. Therefore, we tested various rates of applied $\mathrm{N}$ to see what levels might maximize yield.

\section{MATERIALS AND METHODS}

The Management study was begun in 1987. Plantings of "Cave-in-Rock" switchgrass and "Common" weeping lovegrass were made in June of that year at each of the four locations used in the screening study (Fig. 2-1). Two of the sites (Cecil-North and Davidson) produced strong stands of both grasses. The remaining two (Cecil-south and Appling) were overtaken by crabgrass (Digitaria singularis). The extent of the failure at the latter two sites was such that we replanted in May 1988. Those second plantings were moderately successful; but we eventually chose to abandon the Appling site and the lovegrass plantings on the Cecil-south site. This does not represent a serious difficulty for the overall study, since we eventually obtained three full growing seasons' data on both species in the Management study from two sites and two season's data for switchgrass from a third site. The difficulty in establishment of lovegrass raises some questions about lovegrass' viability as a notillable biomass candidate, however.

In the Management study, we looked factorially at three different $\mathrm{N}$ fertilization rates and two different cutting dates as ways of increasing biomass production of switchgrass and lovegrass. The fertilization treatments of 0,50 , and $100 \mathrm{~kg} \mathrm{~N} / \mathrm{ha}$ were imposed in early-June of each year except 1991. Harvests of the Management study were scheduled in early-September and/or early-November, i.e., we took two cuts (September and November) or only one cut (November). We obtained essentially no regrowth of switchgrass following a September cutting; thus, no second cut was made. On the other hand, lovegrass did provide some regrowth (except in 1990), although perhaps not enough to be economically harvested. Therefore, we report "early" (September) and "late" (November) harvest yields for switchgrass (and 
Figure 2-1. Map showing sites for biomass management study in the Virginia Piedmont, 1987-1991.

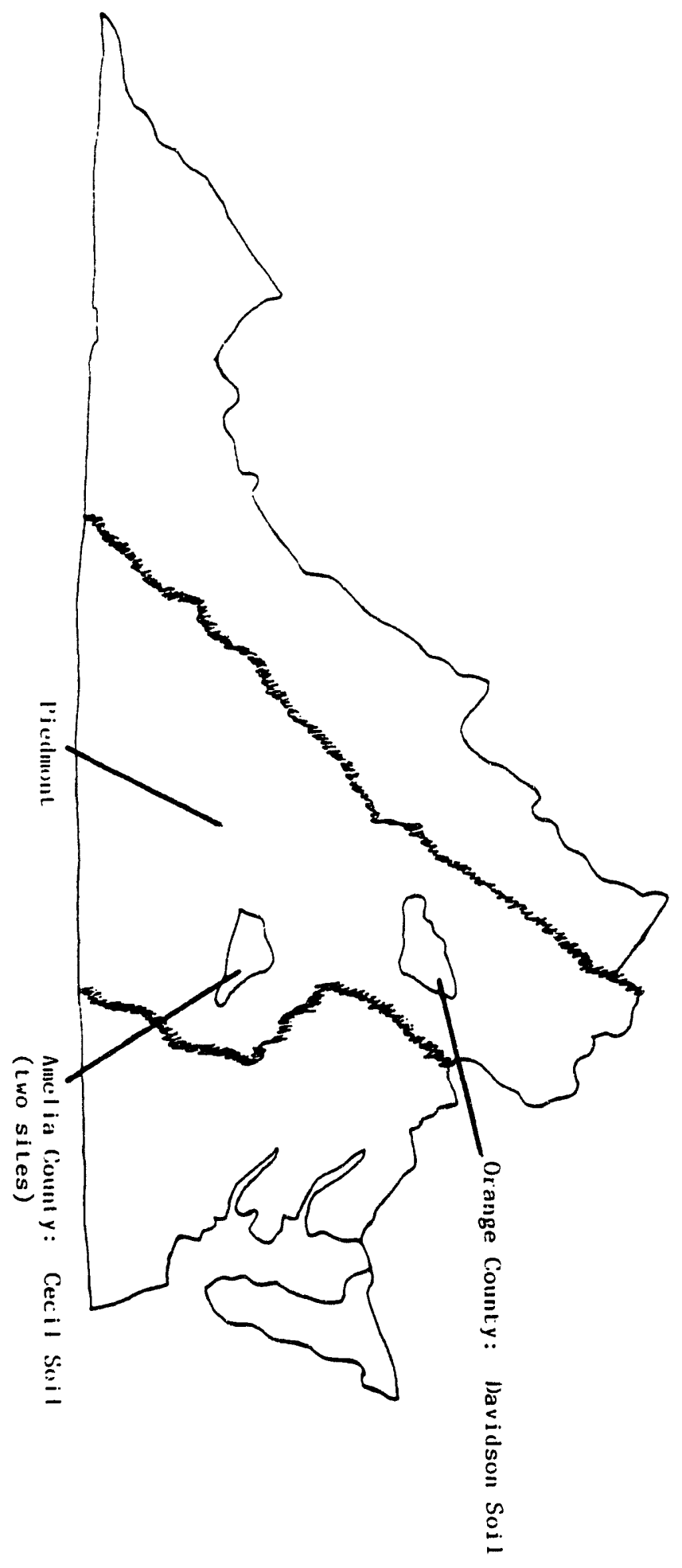


lovegrass in 1990) and one- or two-cut yields for lovegrass in 1988 and 1989.

In 1991, we did not fertilize with $N$, and we made only one harvest -- after the top-growth of each species was killed by a freeze. This approach allowed us to determine whether there were "residual" effects of $N$ fertilization and of the two different harvesting regimes, i.e., did early/multiple harvests perhaps "weaken" the stand? (In other studies, we and others have observed that cutting date and frequency affect performance in subsequent years.)

\section{RESULTS AND DISCUSSION}

In 1988, neither of the species was very responsive to $\mathrm{N}$ fertilization on the different study sites. It would appear that $50 \mathrm{~kg} \mathrm{~N} / \mathrm{ha}$ was near optimal for both species on the cecil soil, and that $\mathrm{N}$ was of no benefit on the Davidson soil (Table 2-1). The Davidson site was obviously more productive in 1988 than was the Cecil-North site (as it was in the screening study also). There were significant differences between the harvest regimes for lovegrass but not switchgrass.

Table 2-1. Seasonal biomass yields (1988) of switchgrass and weeping lovegrass fertilized at three different $N$ rates. Lovegrass was cut either once (early-November) or twice (early-September and early-November). Switchgrass was cut once, either early (early-september) or late (earlyNovember). Sites were located on Davidson soils in Orange county, VA, and on Cecil soils in Amelia county, VA.

\begin{tabular}{|c|c|c|c|c|c|c|}
\hline \multirow[b]{2}{*}{ Soil/site } & \multirow[b]{2}{*}{$\mathbf{N}$} & \multirow[b]{2}{*}{ Applied } & \multicolumn{2}{|c|}{ Switchgrass } & \multicolumn{2}{|c|}{ Lovegrass } \\
\hline & & & Early & Late & Two-cut & One-cut \\
\hline & & $\mathrm{kg} / \mathrm{ha}$ & ----- & ------1 & ha- - - & $--\infty-\infty$ \\
\hline Davidson & & $\begin{array}{r}0 \\
50 \\
100\end{array}$ & $\begin{array}{l}13 \cdot 0 \mathrm{a} \\
13.3 \mathrm{a} \\
13.1 \mathrm{a}\end{array}$ & $\begin{array}{l}12.3 a \\
11.9 a \\
11.7 a\end{array}$ & $\begin{array}{l}14.4 \mathrm{ab} \\
15.1 \mathrm{ab} \\
16.3 \mathrm{a}\end{array}$ & $\begin{array}{l}10.6 \mathrm{c} \\
10.2 \mathrm{c} \\
13.1 \mathrm{~b}\end{array}$ \\
\hline Cecil-N & & $\begin{array}{r}0 \\
50 \\
100\end{array}$ & $\begin{array}{l}6.3 b \\
9.3 a \\
9.0 a\end{array}$ & $\begin{array}{c}8.3 \mathrm{ab} \\
10.5 \mathrm{a} \\
8.6 \mathrm{ab}\end{array}$ & $\begin{array}{l}5.9 \mathrm{c} \\
8.3 \mathrm{ab} \\
9.3 \mathrm{a}\end{array}$ & $\begin{array}{l}5.7 c \\
7.3 b \\
7.6 b\end{array}$ \\
\hline
\end{tabular}

* Means within a site and species followed by the same letter are not different at 0.05 level. 
In the $1989 \mathrm{~N}$ fertilization/cutting frequency study, we obtained somewhat different results than in 1988 (Table 2-2). There appeared to be no advantage to multiple harvests of lovegrass; but we did obtain a response to $\mathrm{N}$ on all sites. We saw a response that seemed to be optimal at around $50 \mathrm{~kg}$ N/ha. That is an encouragingly low rate from an environmental and an economic standpoint. Switchgrass continued to show no response to $\mathrm{N}$ on the Davidson site, but it did show a $50 \mathrm{~kg} / \mathrm{ha}$ optimum on both Cecil sites.

Table 2-2. Seasonal biomass yields (1989) of switchgrass and weeping lovegrass fertilized at three different $N$ rates. Lovegrass was cut either once (early-November) or twice (early-September and early-November). Switchgrass was cut once, either early (early-september) or late (earlyNovember), Sites were located on Davidson soils in Orange county, VA, and on Cecil soils in Amelia county, VA

\begin{tabular}{|c|c|c|c|c|c|c|}
\hline \multirow[b]{2}{*}{ Soil/site } & \multirow[b]{2}{*}{$\mathbf{N}$} & \multirow[b]{2}{*}{ Applied } & \multicolumn{2}{|c|}{ Switchgrass } & \multicolumn{2}{|c|}{ Lovegrass } \\
\hline & & & Early & Late & Two-Cut & one-cut \\
\hline & & $\mathrm{kg} / \mathrm{ha}$ & \multicolumn{4}{|c|}{ 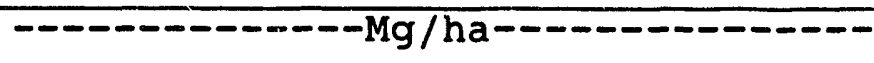 } \\
\hline Davidson & & $\begin{array}{r}0 \\
50 \\
100\end{array}$ & $\begin{array}{l}8.9 a * \\
9.8 a \\
9.1 a\end{array}$ & $\begin{array}{l}6.9 b \\
6.9 b \\
7.0 b\end{array}$ & $\begin{array}{c}9.2 \mathrm{c} \\
11.4 \mathrm{ab} \\
12.8 \mathrm{a}\end{array}$ & $\begin{array}{l}9.4 \mathrm{bc} \\
13.1 \mathrm{a} \\
11.7 \mathrm{a}\end{array}$ \\
\hline Cecil-N & & $\begin{array}{r}0 \\
50 \\
100\end{array}$ & $\begin{array}{r}6.2 b \\
10.0 a \\
9.6 a\end{array}$ & $\begin{array}{l}6.2 b \\
6.4 b \\
6.7 b\end{array}$ & $\begin{array}{l}6.9 c \\
8.9 b \\
9.6 a b\end{array}$ & $\begin{array}{l}8.8 \mathrm{~b} \\
9.2 \mathrm{ab} \\
10.8 \mathrm{a}\end{array}$ \\
\hline Cecil-s & & $\begin{array}{r}0 \\
50 \\
100\end{array}$ & $\begin{array}{l}7.4 \mathrm{bc} \\
9.8 \mathrm{a} \\
9.1 \mathrm{ab}\end{array}$ & $\begin{array}{c}6.0 \mathrm{c} \\
8.4 \mathrm{ab} \\
10.1 \mathrm{a}\end{array}$ & - & - \\
\hline
\end{tabular}

*Means within a site and species followed by the same letter are not different at 0.05 level.

In 1989 , cutting management produced switchgrass results that differed from the earlier year. The early cut provided equivalent or superior yields. In 1988 (Table 2-1), the late harvests of switchgrass tended to be superior to a cutting made two months earlier. We conclude that relatively little growth was made by switchgrass or lovegrass in the last month or two of the "growing season". 
In 1990, we again found only moderate $\mathrm{N}$ responses ( $\mathrm{Table}$ $2-3)$; $50 \mathrm{~kg} \mathrm{~N} / \mathrm{ha}$ appeared to be optimal for both species, except that there was still no positive effect of even $50 \mathrm{~kg}$ $N$ for switchgrass on the Davidson site. Late cutting again proved to be of little value in boosting biomass yields.

Table 2-3. Seasonal biomass yields (1990) of switchgrass and weeping lovegrass fertilized at three different $N$ rates. Each was cut once, either early (early-september) or late (early-November). Sites were located on Davidson soils in orange county, VA, and on Cecil soils in Amelia County, VA.

\begin{tabular}{|c|c|c|c|c|c|c|}
\hline \multirow[b]{2}{*}{ Soil/site } & \multirow[b]{2}{*}{$\mathrm{N}$} & \multirow[b]{2}{*}{ Applied } & \multicolumn{2}{|c|}{ Switcharass } & \multicolumn{2}{|c|}{ Lovegrass } \\
\hline & & & Early & Late & Early & Late \\
\hline & & $\mathrm{kg} / \mathrm{ha}$ & \multicolumn{4}{|c|}{ 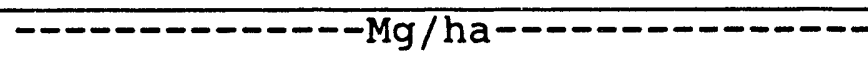 } \\
\hline Davidson & & $\begin{array}{r}0 \\
50 \\
100\end{array}$ & $\begin{array}{l}12.7 \mathrm{a} * \\
11.6 \mathrm{ab} \\
11.1 \mathrm{ab}\end{array}$ & $\begin{array}{c}11.0 \mathrm{ab} \\
9.6 \mathrm{~b} \\
10.3 \mathrm{ab}\end{array}$ & $\begin{array}{l}6.1 \mathrm{~cd} \\
9.0 \mathrm{ab} \\
7.1 \mathrm{bcd}\end{array}$ & $\begin{array}{l}5.5 d \\
7.7 a b c \\
8.6 a b\end{array}$ \\
\hline Cecil-N & & $\begin{array}{r}0 \\
50 \\
100\end{array}$ & $\begin{array}{c}6.3 \mathrm{c} \\
11.0 \mathrm{ab} \\
12.2 \mathrm{a}\end{array}$ & $\begin{array}{l}9.2 b \\
9.4 b \\
9.8 b\end{array}$ & $\begin{array}{l}3.0 b \\
6.6 a \\
6.7 a\end{array}$ & $\begin{array}{l}5.3 a \\
6.4 a \\
6.7 a\end{array}$ \\
\hline Cecil-s & & $\begin{array}{r}0 \\
50 \\
100\end{array}$ & $\begin{array}{c}6.3 \mathrm{c} \\
10.5 \mathrm{ab} \\
11.3 \mathrm{a}\end{array}$ & $\begin{array}{c}4.8 \mathrm{c} \\
9.6 \mathrm{ab} \\
10.5 \mathrm{ab}\end{array}$ & $\begin{array}{l}- \\
-\end{array}$ & $\begin{array}{l}- \\
-\end{array}$ \\
\hline
\end{tabular}

* Means within a site and species followed by the same letter are not different at 0.05 level.

Three key points emerge from the 1991 data in Table 2-4. (1) Both switchgrass and weeping lovegrass were responsive to $\mathrm{N}$ across cutting managements and sites/soils. The $100 \mathrm{~kg} \mathrm{~N}$ rate, which tended to produce the highest yields, was not significantly greater than $50 \mathrm{~kg}$. (2) Early/multiple cuts tended to reduce the yield of both species within any level of $\mathrm{N}$ fertilization. There were some soil/site differences in these trends; switchgrass was equally productive at all $\mathrm{N}$ levels on the Davidson site when it was cut only at the end of the season, and twice-cut lovegrass was not less productive than one-cut within any $N$ level on the cecil site. (3) Productivity of both species varied with site; the Davidson site was more productive than either Cecil site. 
Table 2-4. Biomass yields (1991) of switchgrass and weeping lovegrass following 2 (Cecil-S) or 3 (Davidson and Cecil-N) years of management with three different $N$ rates and two different cutting regimes. Sites were located on Davidson soils in orange county, VA, and Cecil soils in Amelia colinty, VA. In this season, all plots were harvested only once (in November) and no fertilizer was added.

\begin{tabular}{|c|c|c|c|c|c|c|}
\hline \multirow[b]{2}{*}{ Soil/site } & \multirow[b]{2}{*}{$\mathbf{N}$} & \multirow[b]{2}{*}{ Applied } & \multicolumn{2}{|c|}{ Switchgrass } & \multicolumn{2}{|c|}{ Lovegrass } \\
\hline & & & Early & Late & Two-Cut & One-cut \\
\hline & & $\mathrm{kg} / \mathrm{ha}$ & \multicolumn{4}{|c|}{ 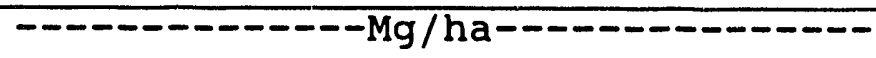 } \\
\hline Davidson & & $\begin{array}{r}0 \\
50 \\
100\end{array}$ & $\begin{array}{r}8.3 \mathrm{ck} \\
9.6 \mathrm{bc} \\
11.2 \mathrm{ab}\end{array}$ & $\begin{array}{l}11.1 \mathrm{ab} \\
11.7 \mathrm{ab} \\
12.0 \mathrm{a}\end{array}$ & $\begin{array}{l}6.6 \mathrm{c} \\
8.5 \mathrm{bc} \\
8.4 \mathrm{bc}\end{array}$ & $\begin{array}{c}7.2 \mathrm{c} \\
9.7 \mathrm{ab} \\
11.2 \mathrm{a}\end{array}$ \\
\hline Cecil-N & & $\begin{array}{r}0 \\
50 \\
100\end{array}$ & $\begin{array}{l}4.4 \mathrm{C} \\
8.4 \mathrm{~b} \\
8.2 \mathrm{~b}\end{array}$ & $\begin{array}{c}8.2 \mathrm{~b} \\
9.5 \mathrm{ab} \\
10.5 \mathrm{a}\end{array}$ & $\begin{array}{c}5.2 \mathrm{c} \\
8.7 \mathrm{ab} \\
10.4 \mathrm{a}\end{array}$ & $\begin{array}{l}6.9 \mathrm{bc} \\
7.2 \mathrm{bc} \\
8.5 \mathrm{ab}\end{array}$ \\
\hline Cecil-s & & $\begin{array}{r}0 \\
50 \\
100\end{array}$ & $\begin{array}{l}4.4 \mathrm{~d} \\
6.5 \mathrm{bc} \\
7.3 \mathrm{ab}\end{array}$ & $\begin{array}{l}5.4 c \\
8.0 a \\
8.1 a\end{array}$ & - & $\begin{array}{l}- \\
-\end{array}$ \\
\hline
\end{tabular}

* Means within a site and species followed by the same letter are not different at 0.05 level.

Tables 2-1 through 2-4 present each year, site, and main effect ( $N$ rate and cutting date) as though they were interacting and therefore needed to be considered separately. This was, in fact, not the case. We tested the numerous possible interactions and found that lovecgrass behaved rather uniformly across sites and years and within $N$ rates and cutting management. The primary exception was some year-toyear differences in response to cutting management at the Davidson site.

More interactions were evident for switchgrass. Because of DOE's interest in this species, we are presenting the data for switchgrass in a somewhat more detailed and slightly different format in Tables 2-5 and 2-6. Each permits comparisons by pooling across main effects wherever they do not interact. For example, in 1991, there were no significant two-way interactions. Therefore, we can 
generalize with more confidence about the main effects of $\mathrm{N}$ fertilization and cutting date, and we can distinguish statistically between sites. In some cases, "trends" in the disaggregated analyses become statistically significant differences.

The summarizations of switchgrass yield responses in Tables 2-5 and $2-6$ serve to reinforce and emphasize the observations already made. Most notable are a modest $N$ response, reduced or equivalent yields with a late-fall (versus early-fall) harvest, and yield variations from site to site and year to year.

\section{CONCLUSIONS}

Taken together (and combined with findinos from the screening study), these data suggest that (1) sw Ltchgrass is equivalent or superior to lovegrass as a biomass producer on the sites/soils tested, (2) $50 \mathrm{~kg} \mathrm{~N} /$ ha may be near optimal for maximizing switchgrass production on these marginal sites, (3) multiple harvests taken in early-september and thereafter do not add significantly to yields, (4) earlySeptember harvests may reduce productivity in subsequent years, and (5) switchgrass yields are quite variable from year to year within a site and from site to site within a year. We will have somewhat more to say about these points in Chapter Four. 
Table 2-5. Biomass yields (1988 through 1990) of switchgrass fertilized with three rates of $\mathrm{N}$ and cut either early (earlySeptember) or late (early-November). Sites were located on Davidson soils in orange county, VA, or on Cecil soils in Amelia County, VA.

\begin{tabular}{|c|c|c|c|c|c|c|}
\hline \multirow[b]{2}{*}{ Year } & \multirow[b]{2}{*}{ Soil/site } & \multirow{2}{*}{$\begin{array}{l}\text { Cutting } \\
\text { management }\end{array}$} & \multicolumn{4}{|c|}{$\mathrm{N}$ applied $(\mathrm{kg} / \mathrm{ha})$} \\
\hline & & & 0 & 50 & 100 & Avg. \\
\hline & & & ----- & $=--\mathrm{Mg} / 1$ & ha--- - & $---\infty$ \\
\hline \multirow[t]{2}{*}{1988} & Davidson & $\begin{array}{l}\text { Early } \\
\text { Late } \\
\text { Avg. }\end{array}$ & $\begin{array}{l}13.0 \\
12.3 \\
12.6 \mathrm{~A} *\end{array}$ & $\begin{array}{l}13.3 \\
11.9 \\
12.6 \mathrm{~A}\end{array}$ & $\begin{array}{l}13.1 \\
11.7 \\
12.4 \mathrm{~A}\end{array}$ & $\begin{array}{c}13.1 \mathrm{a} \\
12.0 \mathrm{a} \\
-\end{array}$ \\
\hline & Cecil-N & $\begin{array}{l}\text { Early } \\
\text { Late } \\
\text { Avg. }\end{array}$ & $\begin{array}{l}6.3 \\
8.3 \\
7.1 \mathrm{~B}\end{array}$ & $\begin{array}{c}9.3 \\
10.5 \\
9.9 \mathrm{~A}\end{array}$ & $\begin{array}{l}9.0 \\
8.6 \\
8.7 A B\end{array}$ & $\begin{array}{c}8.2 a \\
9.2 a \\
-\end{array}$ \\
\hline \multirow[t]{3}{*}{1989} & Davidson & $\begin{array}{l}\text { Early } \\
\text { Late } \\
\text { Avg. }\end{array}$ & $\begin{array}{l}8.9 \\
6.9 \\
7.8 \mathrm{~A}\end{array}$ & $\begin{array}{l}9.8 \\
6.9 \\
8.3 A\end{array}$ & $\begin{array}{l}9.1 \\
7.0 \\
8.0 \mathrm{~A}\end{array}$ & $\begin{array}{c}9.2 a \\
6.9 b \\
-\end{array}$ \\
\hline & Cecil-N & $\begin{array}{l}\text { Early } \\
\text { Late }\end{array}$ & $\begin{array}{l}6.2 b \\
6.2 b\end{array}$ & $\begin{array}{r}10.0 \mathrm{a} \\
6.4 \mathrm{~b}\end{array}$ & $\begin{array}{l}9.6 \mathrm{a} \\
6.7 \mathrm{~b}\end{array}$ & $\begin{array}{l}- \\
-\end{array}$ \\
\hline & Cecil-s & $\begin{array}{l}\text { Early } \\
\text { Late } \\
\text { Avg. }\end{array}$ & $\begin{array}{l}7.4 \\
6.0 \\
6.7 B\end{array}$ & $\begin{array}{l}9.8 \\
8.4 \\
9.1 A\end{array}$ & $\begin{array}{c}9.1 \\
10.1 \\
9.6 \mathrm{~A}\end{array}$ & $\begin{array}{c}8.8 a \\
8.2 a \\
-\end{array}$ \\
\hline \multirow[t]{3}{*}{1990} & Davidson & $\begin{array}{l}\text { Early } \\
\text { Late } \\
\text { Avg. }\end{array}$ & $\begin{array}{l}12.7 \\
11.0 \\
11.8 A\end{array}$ & $\begin{array}{c}11.6 \\
9.6 \\
10.6 \mathrm{~A}\end{array}$ & $\begin{array}{l}11 \cdot 1 \\
10.3 \\
10.7 \mathrm{~A}\end{array}$ & $\begin{array}{c}11.8 \mathrm{a} \\
10.3 \mathrm{~b} \\
-\end{array}$ \\
\hline & Cecil-N & $\begin{array}{l}\text { Early } \\
\text { Late }\end{array}$ & $\begin{array}{l}6.3 c \\
9.2 b\end{array}$ & $\begin{array}{c}11.0 \mathrm{ab} \\
9.4 \mathrm{~b}\end{array}$ & $\begin{array}{r}12.2 \mathrm{a} \\
9.8 \mathrm{~b}\end{array}$ & - \\
\hline & Cecil-s & $\begin{array}{l}\text { Early } \\
\text { Late } \\
\text { Avg. }\end{array}$ & $\begin{array}{l}6.3 \\
4.8 \\
5.5 B\end{array}$ & $\begin{array}{c}10.5 \\
9.6 \\
10.0 \mathrm{~A}\end{array}$ & $\begin{array}{l}11.3 \\
10.5 \\
10.9 A\end{array}$ & $\begin{array}{c}9.4 a \\
8.3 a \\
-\end{array}$ \\
\hline
\end{tabular}

* Means within a site and year followed by the same letter are not different at 0.05 level. 
Table 2-6. Biomass yields (1991) of switchgrass following 2 (Cecil-s) or 3 (Davidson and Cecil-N) years of management with three different $N$ rates and two different cutting regimes. Early regime had been cut in previous years in early september, and the late regime had been cut in early November. In 1991, all plots were harvested only in November.

\begin{tabular}{|c|c|c|c|c|}
\hline \multirow[b]{2}{*}{ soil/site } & \multirow[b]{2}{*}{ applied } & \multicolumn{3}{|c|}{ cutting regime } \\
\hline & & Early & Late & Avg. \\
\hline . & $\mathrm{kg} / \mathrm{ha}$ & \multicolumn{3}{|c|}{$---------\mathrm{Mg} / \mathrm{ha}----\cdots----$} \\
\hline Davidson & $\begin{array}{r}0 \\
50 \\
100 \\
\text { Avg. }\end{array}$ & $\begin{array}{c}8.3 \mathrm{~b} \\
9.6 \mathrm{ab} \\
11.2 \mathrm{a} \\
9.7 \mathrm{~B}\end{array}$ & $\begin{array}{l}11.2 \mathrm{a} \\
11.7 \mathrm{a} \\
12.0 \mathrm{a} \\
11.6 \mathrm{~A}\end{array}$ & $\begin{array}{c}9.7 a \\
10.7 a \\
11.6 a \\
-\end{array}$ \\
\hline $\operatorname{Cecil}-\mathrm{N}$ & $\begin{array}{r}0 \\
50 \\
100 \\
\text { Avg. }\end{array}$ & $\begin{array}{l}4.4 \\
8.5 \\
8.2 \\
7.0 \mathrm{~B}\end{array}$ & $\begin{array}{c}8.2 \\
9.5 \\
10.5 \\
9.4 \mathrm{~A}\end{array}$ & $\begin{array}{l}6.3 b \\
9.0 a \\
9.3 a\end{array}$ \\
\hline Cecil-s & $\begin{array}{r}0 \\
50 \\
100 \\
\text { Avg. }\end{array}$ & $\begin{array}{l}4.4 \\
6.5 \\
7.3 \\
6.1 \mathrm{~B}\end{array}$ & $\begin{array}{l}5.4 \\
8.0 \\
8.1 \\
7.2 \mathrm{~A}\end{array}$ & $\begin{array}{l}4.9 b \\
7.3 a \\
7.7 a \\
-\end{array}$ \\
\hline Pooled & $\begin{array}{r}0 \\
50 \\
100 \\
\text { Avg. }\end{array}$ & $\begin{array}{l}5.8 \\
8.2 \\
9.0 \\
7.6 \mathrm{~B}\end{array}$ & $\begin{array}{c}8.2 \\
9.8 \\
10.2 \\
9.4 \mathrm{~A}\end{array}$ & $\begin{array}{c}7.0 \mathrm{~b} \\
9.0 \mathrm{a} \\
9.6 \mathrm{a} \\
-\end{array}$ \\
\hline $\begin{array}{l}\text { Davidson } \\
\text { Cecil-N } \\
\text { Cecil-s } \\
\text { Average }\end{array}$ & $\begin{array}{l}\text { pooled } \\
\text { pooled } \\
\text { pooled }\end{array}$ & $\begin{array}{l}9.7 \\
7.0 \\
6.1 \\
7.6 \mathrm{~B}\end{array}$ & $\begin{array}{c}11.6 \\
9.4 \\
7.2 \\
9.4 \mathrm{~A}\end{array}$ & $\begin{array}{c}10.7 \mathrm{a} \\
8.2 \mathrm{~b} \\
6.6 \mathrm{c} \\
-\end{array}$ \\
\hline
\end{tabular}

* Means within a site followed by the same letter are not different at 0.05 level. 


\section{DOUBLE-CROPPING WITH RYE AND WINTER-ANNUAL LEGUMES IN A BWITCHGRASS BIOMASS RRODUCTION SYSTEM}

As part of the Management study, we considered the feasibility of double crops. We do not suppose that switchgrass or lovegrass can remain perennially productive without $N$ additions, but they might be able to obtain their $N$ needs from a winter-annual legume inserted into the biomass-production system. Many winter annuals can complete their life cycle within the "window" provided by the dormant period of the warm-season perennials, i.e., early-fall to mid-spring. We report here some findings with this approach as well as double-cropping with rye (secale cereale).

\section{MATERIALS AND METHODS}

This study was part of the overall Management study, which was described in Chapter Two. Beginning in fall 1988, four winter-annual crops were no-till planted into the stubble of switchgrass that had been harvested in lateAugust/early-september. In addition to the small grain ("Abruzzi" rye), we planted crimson clover (Trifolium incarnatum), arrowleaf clover (Trifolium hastata), and hairy vetch (Vicia villosa). Because of poor winter survival by arrowleaf clover in the first two seasons, we substituted alfalfa (Medicago sativa) for arrowleaf in fall 1990.

The rye was fall-fertilized with $40 \mathrm{~kg} \mathrm{~N} / \mathrm{ha}$ and was harvested in mid-May, when it was heading. At the same time, the winter-annual legumes were killed by spraying with 2,4dichlorophenoxyacetic acid $(2,4-D)$, permitting switchgrass to grow without further competition. Because the hairy vetch appeared to be causing significant competition for early growth of the switchgrass, we moved the 2,4-D kill date to earlier in May in succeeding years. At time of spraying, we sampled quadrates from each plot to determine the biomass present. We did not harvest the killed legumes; they were allowed to decompose in place. Rye-producing plots received $50 \mathrm{~kg} \mathrm{~N} / \mathrm{ha}$ in June.

\section{RESULTS AND DISCUSSION}

We harvested quadrates from each legume-containing plot in May 1989 just before spraying with 2,4-D to kill the legumes. The spring composition of stands and the spring biomass (Table $3-1$ ) revealed switchgrass was the dominant species even in early May. Hairy vetch was the most vigorous legume at the time of killing. In fact, it appeared to 
overly dominate those plots into which it was interseeded. Arrowleaf clover did not provide as much biomass as the other two legumes. Crimson clover visual'y seemed to represent a good compromise between too little legume (too little $N$ ) and too much legume (smothering the switchgrass).

Table 3-1. Botanical composition (legume biomass as a percentage of total biomass) and biomass in switchgrass plots interplanted with winter-annual legumes at two sites in the Virginia Piedinont and measured in May 1989.

Botanical

Composition

Biomass

8 of total

$\mathrm{Mg} / \mathrm{ha}$

Crimson clover

36

12

1.9

Arrowleaf clover

46

0.5

Hairy vetch

2.4

Fall yields of switchgrass biomass in plots that had the winter-annual legumes and $\mathrm{N}$ treatments are shown in Table 32. The responses varied between sites. On the Davidson soils, crimson and arrowleaf clover intercropping resulted in yields that were equivalent to all $\mathrm{N}$ treatments (including 0 N) ; but hairy vetch appeared to inhibit switchgrass yields. The hairy vetch plots were visibly reduced in vigor throughout the growing season, probably reflecting excessive competition. The poor response to crimson clover intercropping at the cecil site was surprising, especially in light of the opposite results on the Davidson site.

The 1989 rye spring yields and the subsequent fall yields of switchgrass from the double-cropped plots are shown in Table 3-3. It would appear that rye double-crops were not economic; there was no increase in total biomass, perhaps because switchgrass productivity was reduced by competition from the rye.

Results of the 1989-90 double-cropping trial are shown in Tables 3-4 through 3-6. Hairy vetch again produced the most biomass, and arrowleaf was the least productive (Table 3-4). We had good stands of all of the legumes in the Fall. (We counted ample seeding populations at 5 to 6 weeks after planting each year of the study.) The poor productivity of 
some of the legumes appeared to be due to loss of seedlings over winter. Stand loss was perhaps partially due to freezing injury, but we saw evidence that much seedling damage resulted from depredation. We suspect slugs, insects, and/or some vertebrates may have seriously reduced legume populations, especially for arrowleaf clover.

Table 3-2. Biomass of switchgrass grown on two sites in the Virginia Piedmont following fertilization with three $\mathrm{N}$ rates or three winter-annual legume cover crops. Harvests were made in September 1989.

Soil/site

Treatment

Davidson

Cecil-N

$-------\cdots-M g / h a$

Crimson clover

Arrowleaf clover

Hairy vetch

$9.8 a *$

$9.8 a$

$7.6 \mathrm{c}$

$8.9 a b c$

$0 \mathrm{~kg} \mathrm{~N} / \mathrm{ha}$

$50 \mathrm{~kg} \mathrm{~N} / \mathrm{ha}$

$100 \mathrm{~kg} \mathrm{~N} / \mathrm{ha}$
$9.8 \mathrm{a}$

$9.1 \mathrm{ab}$
$6.5 b c$

$7.9 \mathrm{~b}$

$5.5 \mathrm{c}$

$6.2 \mathrm{bc}$

$10.0 \mathrm{a}$

$9.6 \mathrm{a}$

* Means within a column followed by same letter are not different at 0.05 level.

In early september 1990, we again harvested the switchgrass from the legume cover-crop plots as well as one set of 0,50 , and $100 \mathrm{~kg} \mathrm{~N} /$ ha plots. The yields are reported in Table 3-5. On the Davidson site, which was not $N$ responsive, hairy vetch appeared to reduce switchgrass production. We feel the hairy vetch treatment was detrimental because we failed to kill it early enough. on the Cecil sites, we did see some evidence of a modest benefit from the clovers. Hairy vetch, on the other hand, was again detrimental probably because of residual effects from switchgrass 1989 stand reductions (due to competition from hairy vetch in the spring). Results from the rye-switchgrass double crop showed no double-cropping advantage (Table 3-6). 
Table 3-3. Yield of rye double-cropped with switchgrass and yield of switchgrass following rye or single-cropped when grown on two soils in the Virginia Piedmont, 1989.

\begin{tabular}{llcc} 
& & \multicolumn{2}{c}{ Site/soil } \\
\cline { 3 - 4 } Treatment & $\begin{array}{c}\text { Harvest } \\
\text { Month }\end{array}$ & Davidson & Cecil-N \\
\hline & & ---- Mg/ha--- \\
Double crop & May \\
Rye & Sept. & 2.1 & 2.3 \\
Total & May \& Sept. & 10.5 & 6.1 \\
Switchgrass alone & Oct. & 9.8 & 10.0 \\
\hline
\end{tabular}

Table 3-4. Biomass in switchgrass plots interplanted with winter-annual legumes at three sites in the virginia Piedmont, May 1990.

$$
\text { Soil/site }
$$

Species

Davidson

Cecil-N

Cecil-s

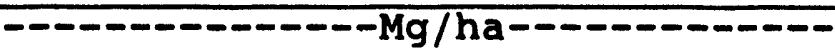

Crimson clover

Arrowleaf clover

Hairy vetch
1.1

0.1

3.1
2.6

0.3

2.0
1.7

1.2

3.5 
Table 3-5. Biomass of switchgrass grown on three sites in the Virginia Piedmont following fertilization with three rates of $N$ or three winter-annual legume cover crops. Harvests were made in september 1990.

Soil/site

Treatment

Davidson

Cecil-N

Cecil-s

\begin{tabular}{lccc} 
& & & \\
Crimson clover & $11.7 \mathrm{ab}$ & $7.8 \mathrm{~b}$ & $9.1 \mathrm{~b}$ \\
Arrowleaf clover & $11.0 \mathrm{ab}$ & $8.0 \mathrm{~b}$ & $7.2 \mathrm{c}$ \\
Hairy vetch & $7.9 \mathrm{c}$ & $5.0 \mathrm{c}$ & $5.7 \mathrm{c}$ \\
& & & \\
$0 \mathrm{~kg} / \mathrm{ha}$ & $12.7 \mathrm{a}$ & $6.3 \mathrm{bc}$ & $6.2 \mathrm{c}$ \\
$50 \mathrm{~kg} / \mathrm{ha}$ & $11.6 \mathrm{ab}$ & $11.0 \mathrm{a}$ & $10.5 \mathrm{ab}$ \\
$100 \mathrm{~kg} / \mathrm{ha}$ & $11.1 \mathrm{ab}$ & $12.2 \mathrm{a}$ & $11.3 \mathrm{a}$ \\
\hline
\end{tabular}

*Means within a column followed by same letter are not different at 0.05 level.

Table 3-6. Yield of rye double-cropped with switchgrass and yield of switchgrass following rye or single-cropped when grown on three sites in the virginia Piedmont, 1990.

\begin{tabular}{lcccc}
\hline & \multicolumn{3}{c}{ Site/Soil } \\
Treatment & $\begin{array}{c}\text { Marvest } \\
\text { Month }\end{array}$ & Davidson & Cecil-N & Cecil-s \\
\hline & & $-0.0-0$ & 0.2 \\
Double crop & May & 3.6 & 0.2 & 9.7 \\
$\begin{array}{l}\text { Rye } \\
\text { Switchgrass }\end{array}$ & Sept. & 7.8 & 8.5 & 9.9 \\
Total & May \& Sept. & 11.4 & 8.7 & 10.5 \\
Switchgrass alone & Oct. & 11.6 & 11.0 & \\
\hline
\end{tabular}


Spring 1991 yields of the winter-annual crops are shown in Table 3-7. No data are reported for alfalfa, because all stands were essentially lost to winter injury or depredation. The rye stands on both Cecil sites were also lost. We had determined to fertilize rye with the prescribed $40 \mathrm{~kg} \mathrm{~N} / \mathrm{ha}$ in February, but apparently there was not sufficient $N$ in the soil to "carry" the rye to that point. The Davidson site was more conducive to rye. In fact, 1990-91 proved to be one of its better seasons (of the three tested). We might point out that none of the rye yields reported in this study is exceptional. In keeping with a low-input rationale, we used less-than-optimal $\mathrm{N}$ rates for the winter-annual crop.

Table 3-7. Biomass of switchgrass plots interplanted with winter-annual legumes or rye at three sites in the Virginia Piedmont, April 1991.

Soil/site

$\begin{array}{lll}\text { Species } & \text { Davidson Cecil-N }\end{array}$

\begin{tabular}{lccc}
\hline & & & \\
Crimson clover & 2.3 & 0.5 & 1.1 \\
Hairy vetch & 2.8 & 1.5 & 1.8 \\
Rye & 3.3 & - & - \\
\hline
\end{tabular}

Crimson clover productivity was quite variable across the sites. Hairy vetch was again more productive than clover at each of the sites. We feel that we killed the hairy vetch before it provided significant competition to switchgrass in 1991, but the stands of switchgrass still appeared to be reduced by the competition from hairy vetch in spring 1989.

Results of the 1991 double-cropping work cannot be compared directly with the previous years' for four reasons. (1) The double-cropped switchgrass harvests were not made in September. Rather, the switchgrass accumulated to the end of the season (early November) to look for "residual" effects of double cropping. (2) We substituted alfalfa for the twicefailed arrowleaf clover. The alfalfa double-crop was no more successful, however. We obtained good seedling stands in fall 1990, but the plots were essentially free of alfalfa in mid-April. The problem appeared to have been largely due to 
insectislug damage. As a consequence, arrowleaf cloveralfalfa double crops were in essence a second $0-\mathrm{N}$ plot within each replication. (3) Rye was a complete failure on both Cecil sites, but those plots did receive the $40 \mathrm{~kg} \mathrm{~N} / \mathrm{ha}$ allocated for rye. (4) Nitrogen fertilization was not supplied to "control" plots in 1991 (see Chapter 2).

The 1991 double-crop sesidual results are shown in Table 3-8. The most significant finding would appear to be that double-cropping of winter-annual legumes provides essentially no benefit when compared to $0 \mathrm{~kg} \mathrm{~N} / \mathrm{ha}$. The only exception was for hairy vetch at cecil-s, where it brought switchgrass yields up to levels equivalent to $50 \mathrm{~kg} \mathrm{~N} / \mathrm{ha}$. The results are surprising; crimson clover should have made substantial amounts of $N$ available to switchgrass without creating undue spring competition. (Crimson clover did show benefit at some sites in previuus years.) The increase in yield of switchgrass following hairy vetch at the cecil-s site shows the legumes have promise as $\mathrm{N}$ providers, but their management is still problematic.

Table 3-8. Biomass of switchgrass grown on three sites in the Virginia piecmont following fertilization with three rates of $N$, three winter-annual legume cover crops, or a rye double crop. Harvests were made in November 1991.

Soil/site

\begin{tabular}{lccc} 
Treatment & Davidson & Cecil-N & Cecil-s \\
\hline & - & & \\
Crimson clover & $8.2 \mathrm{bc}$ & $5.4 \mathrm{~b}$ & $4.7 \mathrm{c}$ \\
Arrowleaf/alfalfa & $.2 \mathrm{bc}$ & $5.3 \mathrm{~b}$ & $4.4 \mathrm{C}$ \\
Hairy vetch & $6.3 \mathrm{bc}$ & $4.3 \mathrm{~b}$ & $6.1 \mathrm{~b}$ \\
$0 \mathrm{~kg} \mathrm{~N} / \mathrm{ha}$ & $8.3 \mathrm{bc}$ & $4.4 \mathrm{~b}$ & $4.4 \mathrm{c}$ \\
$50 \mathrm{~kg} \mathrm{~N} / \mathrm{ha}$ & $9.6 \mathrm{ab}$ & $8.4 \mathrm{a}$ & $6.5 \mathrm{ab}$ \\
$100 \mathrm{~kg} \mathrm{~N} / \mathrm{ha}$ & $11.2 \mathrm{a}$ & $8.2 \mathrm{a}$ & $7.3 \mathrm{a}$ \\
Rye double crop & $7.5 \mathrm{c}$ & $5.3 \mathrm{~b}$ & $6.4 \mathrm{ab}$
\end{tabular}

* Means within a column followed by the same letter are not different at 0.05 level. 
In theory at least, winter-annual legumes should provide a productive advantage to switchgrass receiving no synthetic $\mathrm{N}$ fertilizer. In many other studies, where legume cover crops have been used in rotations with corn (Zea mays), the legumes have boosted corn yields significantly. Switchgrass is a perennial, but its growing season is not very different from corn's. If switchgrass is cut in early september (by which time it has made essentially all of its growth for the season), legumes can be readily planted into the stubble. The winter-annual legumes typically produce some growth in the fall, over-winter in a rosette stage, and develop rapidly in the spring. We saw good development of two of the legumes tested (crimson clover and hairy vetch), but we did not see a consistent yield advantage for the following season's switchgrass. The problem apparently stems from spring-time competition between the rapidly growing legumes and the early, low growth of the switchgrass.

Rye double crops, where the winter-annual rye is planted into switchgrass stubble and harvested for its biomass in spring, did not appear to be a viable cropping system. We obtained good early stands of rye, but winter survival and or early spring growth was not very encouraging. The switchgrass plots were likely rather $N$ deficient. With a low input philosophy, we did not fertilize the rye crop sufficiently to maximize its production. We also had to remove the rye before it made the bulk of its spring growth. Alternatively, the switchgrass would likely have suffered from competition. We suspect that competition occurred to some u:idesirable degree in any event. 


\section{CHAPTER FOUR}

\section{SUMOMARY AND CONCLUSIONS}

Virginia Tech has completed a four-year study of the management of switchgrass and lovegrass for biomass production. The findings suggest both species respond to $\mathrm{N}$ fertilization, as would be expected; but each surprisingly appeared to have an optimum of about $50 \mathrm{~kg} \mathrm{~N} / \mathrm{ha}$. On one of the study sites (Davidson), the advantage of added $N$ was not apparent in switchgrass until the fourth year of the study. Residual $\mathrm{N}$ within the soil profile presumably provided enough of that critical nutrient to bring the plantings up to the level of productivity dictated by the next most limiting factor(s). We do not rule out the possibility that some microbiological process(s) may have been providing $N$ to switchgrass at this site. Soil organisms (sans legumes) have been shown to provide sufficient $N$ for perennial growth of some grasses in prairie ecosystems.

Evidence from the cutting frequency results (included factorially in the two-species $\mathrm{N}$-management study) suggests multiple cuttings are not advantageous. In fact, they may reduce yields. However, our study was designed to look at harvests made relatively late in the growing season. We chose the early-september dates, because that was the appropriate time to cut to allow for planting of winterannual intercrops. These late-summer cuttings represented the "control" for treatments including winter-annuals.

We can say with some certainty that late-summer harvests of switchgrass do not allow for significant regrowth before the end of the season. Lovegrass did produce some additional biomass but probably not enough to be economically feasible to harvest. The switchgrass plants left standing till November produced more additional yield in 1988. In succeeding years, however, there was a trend toward or a significant reduction in yield when the switchgrass was left standing. Nitrogen did not appear to be the factor limiting regrowth, since there was no difference between $0 \mathrm{~kg} \mathrm{~N} / \mathrm{ha}$ and $100 \mathrm{~kg} \mathrm{~N} / \mathrm{ha}$ in this regard.

Our own work, as well as that of David Bransby at Auburn University, suggests that two harvests of switchgrass may boost $y$ ields if the first cut is made in early summer. In a parallel study we did at the Davidson site (not part of the HECP work), we cut switchgrass in June and early-fall; yields for the two cuts exceeded a single, early-fall harvest. We conclude that proper cutting management may boost biomass production by switchgrass, but improper management may reduce 
yields. More research is needed on timing of harvests.

This study on cutting frequency produced another finding that may be of significance. In 1991, we made only one harvest across all treatmentis; that was in late-fall after top growth of both switchgrass and lovegrass was killed by freeze. The observations from all three sites suggested that the early-cut system reduced switchgrass productivity in a succeeding year. If switchgrass was cut in early-september, it produced less biomass in the next year than when cut only in early-November. The effect may have to do with removal of top growth before it can translocate reserves back into below-ground storage sites. Alternatively, it may be a result of putting a "drain" or stress on the plants to produce new growth in the fall, when they are normally moving into a different physiological state. In any event, these results suggest late-summer/early-fall cuts may be disadvantageous. This has obvious implications for earlyfall planting of winter annuals. (We observed also, though, that early-september cuttings sometimes provided more biomass within the year than did end-of-season cuttings. This presents an interesting "dilemma" for the potential biomass producer.)

As regards the use of winter-annual legumes to substitute for synthetic $N$ fertilizer, we saw some evidence of a positive effect. Although we did not attempt to measure the actual $N$ represented by the legume biomass, the literature suggests it should have been the equivalent of 50 $\mathrm{kg} \mathrm{N} / \mathrm{ha}$ or more for both crimson clover and hairy vetch. In most years and sites, switchgrass yields following the legumes did not equal yields following $50 \mathrm{~kg} \mathrm{~N} / \mathrm{ha}$. In fact, the yields following the legumes were sometimes less than those in "control" plots receiving no $\mathrm{N}$.

The lack of a switchgrass response to winter-annual legumes may stem from competition between the two crops. In the first spring (1989) following winter-annual plantings, we undoubtedly delayed too long in killing the hairy vetch with 2,4-D. Hairy vetch has a vigorous, vining growth habit. It was shading early growth of the switchgrass, and it perhaps reduced availability of other factors such as nutrients (including $N$ ) until the legume died and released nutrients tied up in its biomass. We suppose there is little competition for water, since the switchgrass roots can draw on deeper soil moisture than the legumes can.

The timing of the 2,4-D application to the legumes is probably crucial. If it is too early, insufficient $N$ will accumulate. If it is too late, the switchgrass may suffer. 
In the summer of 1989 , it was easy to distinguish the hairyvetch-treatment plots from all others, because those plots were distinctly less vigorous with more weeds. (Switchgrass usually develops a thick stand that permits no weed encroachment.)

Double-cropping switchgrass with the winter-annual legumes may have promise, but more work is needed in selection of species as well as the timing of the broad-leaf herbicide. Crimson clover seemed to provide the best match phenologically and morphologically with switchgrass; and we obtained consistently good stands; but it failed to consistently boost switchgrass yields. Arrowleaf clover and alfalfa are not promising because of difficulty in maintaining stands. We have already described the phenological and morphological "mismatch" between hairy vetch and switchgrass. Other species, perhaps to include perennials such as sericea lespedeza, may have promise for double-cropping with switchgrass.

A rye crop can be grown in the "window" from switchgrass harvest until spring. But the varieties of rye suitable for Virginia's winters do not match well phenologically with switchgrass. (Rye is the earliest of the winter-annual small grains; it matures before either barley or wheat.) The amount of rye biomass developed by late-April (when rye should be removed to halt competition with the early growth of switchgrass) is not sufficient to make its contribution to total biomass production very economic. We suggest that 2 to $4 \mathrm{Mg} / \mathrm{ha}$ is the most that might reasonably be expected for an annual average. Higher yields might be possible with increased $\mathrm{N}$ and delayed cutting, but each of these strategies has drawbacks.

The major conclusions from the four-year "Management study" are these: (1) switchgrass biomass production may be optimized under our "marginal" conditions with about $50 \mathrm{~kg}$ N/ha; (2) switchgrass makes little growth after being cut in early-september, but earlier harvests may boost seasonal totals; (3) winter-annual legumes must be managed carefully if they are used to provide biologically fixed $N$ for switchgrass; (4) rye does not appear to be a very viable double-crop with switchgrass; (5) lovegrass is essentially equivalent to switchgrass under the conditions existing in our study; (6) lovegrass yields and stand vigor appear to decline after three or four years; (7) early-september harvests of both switchgrass and lovegrass may reduce biomass production in succeeding years; and (8) within a year, there appears to be a reduction in harvestable switchgrass biomass between early-september and the end of the season. Several 
of these findings hold promise for improved management of switchgrass as a biofuels crop. 


\section{INTERNAL DISTRIBUTION}

1. R. S. Carlsmith

2-16. J. H. Cushman

17. A. R. Ehrenshaft

18. R. L. Graham

19. S. G. Hildebrand

20. S. B. McLaughlin

21. W. A. McNabb

22. J. W. Ranney

23-37. A. Turhollow
38. G. A. Tuskan

39. R. I. Van Hook

40. L. L. Wright

41. Central Research Library

42-57. ESD Library

58-59. Laboratory Records Dept

60. Laboratory Records

61. ORNL Patent Section

62. ORNL Y-12 Technical Library

\section{EXTERNAL DISTRIBUTION}

63. C. S. Accola, Iowa State University, 1496 Agronomy Hall, Ames, IA 50011

64. I. C. Anderson, Iowa State University, Dept. of Agronomy, Ames, IA 50011

65. P. C. Badger, SE Regional Biomass Energy Program, 435 Chemical Engr. Building, Muscle Shoals, AL 35660

66. J. A. Balasko, Division of Plant and Soil Science, West Virginia University, Morgantown, WV 26506

67. A. A. Boe, South Dakota State University, Dept. of Plant Science, Brooking, SD 57007

68. D. I. Bransby, Auburn University, Dept. of Agronomy \& Soils, 202 Funchess Hall, Auburn, AL 36849-4109

69. D. R. Buxton, Iowa State University, Agricultural Research Service, 1577 Agronomy Hall, Ames, IA 50011

70. R. Q. Cannell, Crop and Soil Environmental Sciences, Virginia Tech, Blacksburg, VA 24061

71. I. T. Carlson, Iowa State University, Dept. of Agronomy, Ames, IA 50011-1010

72. H. Chum, National Renewable Energy Laboratory, 1617 Cole Blvd., Golden, CO 80401-3393

73. K. Clay, Indiana University, Department of Biology, 1575 Linden Drive, Bloomington, IN 47405

74. M. Collins, University of Kentucky, Dept. of Agronomy, N-122 Ag. Sci. Bldg. North, Lexington, KY 40546-0091

75. B. Conger, University of Tennessee, Dept. of Plant and Soil Science, Knoxville, TN 37901-1071

76. R. Conway, U.S. Department of Agriculture, Office of Energy, OE, RM 144E, Admin. Bldg, Washington, DC 20250

77. J. H. Cook, National Audubon Society, Scully Science Ctr, 550 South Bay Avenue, Islip, NY 11751

78. J. S. Cundiff, Virginia Tech, Dept of Agricultural Engineering, Blacksburg, VA 24061-0303

79-83. W. L. Daniels, Virginia Tech, Dept. of Agronomy, Blacksburg, VA 24061

84. G. Dishner, Dept. Mines, Minerals, Energy, 2201 West Broad Street, Richmond, VA 23220 
85. D. H. Dawson, 3015 S. River Road., P.O. Box 1321, Rhinelander, WI 54501

86. B. English, University of Tennessee, Dept Agric Economics \& Rural Sociology, P.O. Box 1071, Knoxville, TN 37901-1071

87. J. E. Ferrell, U.S. Dept. of Energy, Biofuels Systems Division, CE 331 Forrestal Bldg., Washington, DC 20545

88. E. E. Gavett, Agricultural Economist, 2608 Bowling Green Drive, Vienna, VA 22180

89. M. Genthner, Crop and Soil Environmental Sciences, Virginia Tech, Blacksburg, VA 24061

90. W. Glasser, 210B Cheatham Hall, Virginia Tech, Blacksburg, VA 24061

91. J. T. Green, Jr., Department of Crop Sciences, North Carolina State University, Raleigh, NC 27695-7620

92. D. Hall, Crop and Soil Environmental Sciences, Virginia Tech, Blacksburg, VA 24061

93. L. Harris. USDA Cooperative State Research Service, Aerospace Bldg., Rm. $329 \mathrm{~N}$, Washington, DC 20250-2200

94. J. Hatfield, USDA/ARS, National Soil Tilth Lab, 2150 Pammel Drive, Ames, IA 50011

95. N. Hinman, National Renewable Energy Laboratory, 1617 Cole Boulevard, Golden, CO 80401

96. G. L. Jubb, 104 Hutcheson Hall, Virginia Tech, Blacksburg, VA 24061

97. D. W. Meyer, North Dakota State University, Crop and Weed Sciences Department, P. O. Box 5051, Fargo, ND 58105-5051

98. S. Nagle, Crop and Soil Environmental Sciences, Virginia Tech, Blacksburg, VA 24061

99. R. P. Overend, National Renewable Energy Laboratory, Fuels \& Chemicals Research \& Engr. Div., 1617 Cole Blvd., Golden, CO 80401-3393

100-119. D. J. Parrish, Virginia Tech, Dept. of Agronomy, Blacksburg, VA 24061

120. J. V. Perumpral, Agricultural Engineering, Virginia Tech, Blacksburg, VA 24061

121. C. S. Prakash, Tuskegee University, School of Agriculture, Milbank Hall, Tuskegee, AL 36088

122. M. Rasnake, Research and Education Center, P.O. Box 469, Princeton, KY 42445

123. P. Rasnick, Sponsored Programs, 301 Burruss Hall, Virginia Tech, Blacksburg, VA 24061

124. J. H. Reynolds, Dept. of Plant and Soil Science, University of Tennessee, Knoxville, TN 37901-1071

125. G. L. Riner, U.S. Department of Energy, P. O. Box 2008, Oak Ridge, TN 37831-6269

126. R. J. Des Roches, Dept. Mines, Minerals, Energy, 2201 West Broad Street, Richmond, VA 23220

127. R. A. Samson, REAP-Canada, Box 125 Glenaladale House, Ste-Anne-DeBellevue, Quebec, H9X 1CO

128. M. A. Sanderson, The Texas A\&M University, Texas Agricultural Experiment Station, Route 2, Box 00, Stephenville, TX 76401

129. R. E. Seward, Dept. Agric. \& Consum. Serv., P.O. Box 1163, Room 210, Richmond, VA 23209

130. D. Starner, N. Piedmont Ag. Exp. Stn., Orange, VA 22960 
131. L. A. Swiger, 104 Hutcheson Hall, Virginia Tech, Blacksburg, VA 24061

132. C. M. Taliaferro, Oklahoma State University, 481 Agriculture Hall, Department of Agronomy, Stillwater, OK 74078

133. J. H. Turnbull, Electric Power Research Institute, 3412 Hillview Avenue, P.O. Box 10412, Palo Alto, CA 94303

134. D. Vaughan, Agricultural Engineering, Virginia Tech, Blacksburg, VA 24061

135. K. Vogel, University of Nebraska, USDA-ARS, 332 Keim Hall, Lincoln, NE 68583-0910

136. A. Wiselogel, National Renewable Energy Laboratory, 1617 Cole Blvd., Golden, CO 80401

137-141. D. D Wolf, Virginia Tech, Dept. of Agronomy, Blacksburg, VA 24061

142. Office of Assistant Manager for Energy Research and Development, U.S. Department of Energy Field Office, P.O. Box 2001, Oak Ridge, TN 37831-8600

143-144. Office of Scientific and Technical Information, P.O. Box 62, Oak Ridge, TN 37831 

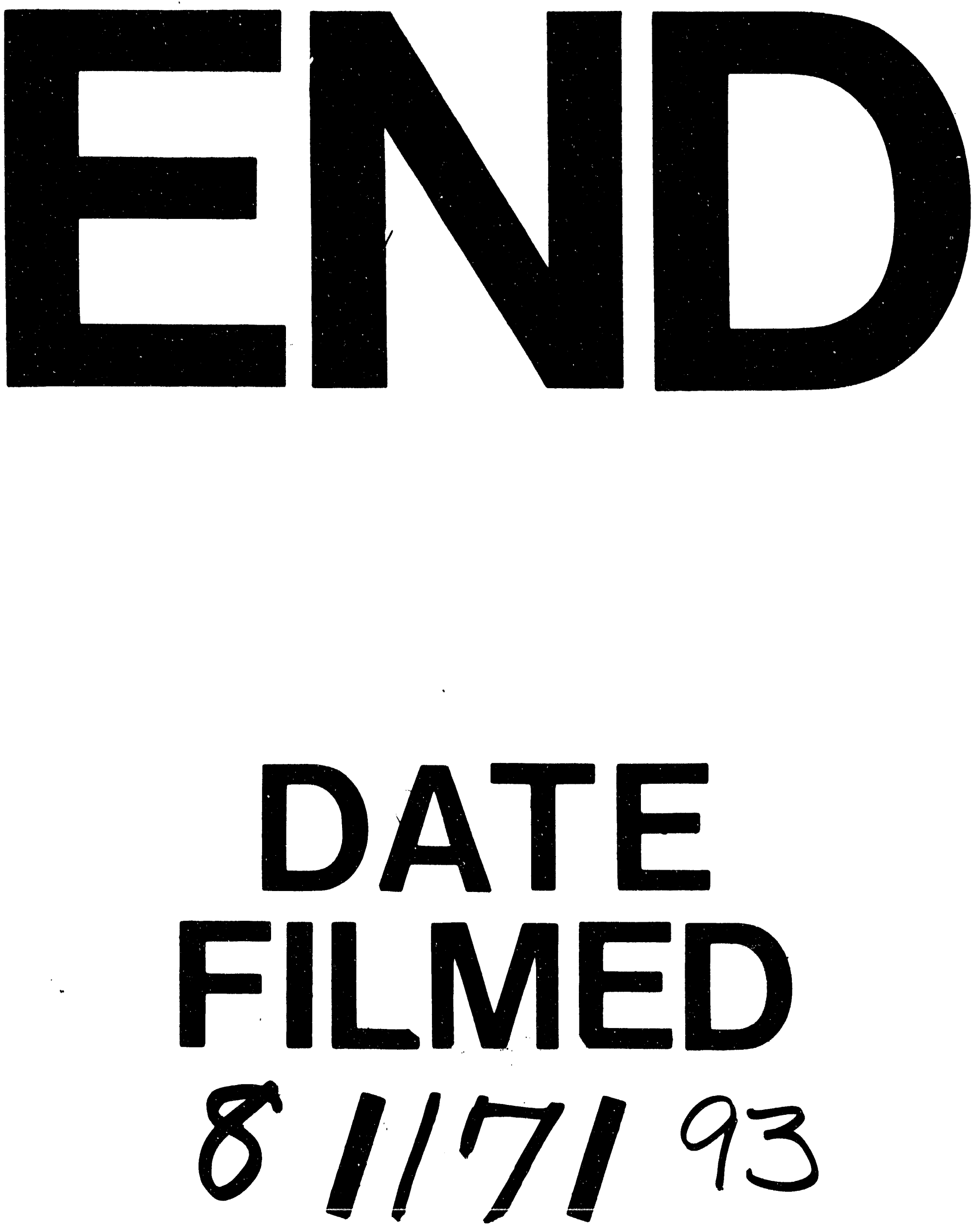

1 
